\title{
SUSTAINABLE TOURISM DEVELOPMENT
}

\author{
IWONA NiEDZIÓEKA ${ }^{1}$
}

Alcide De Gasperi University of Euroregional Economy in Józefów (Poland)

\begin{abstract}
The article presents the main ideas of sustainable tourism - new form of tourism promoted by authorities, environmental and social institutions and international organizations. It implies taking into account economic, environmental, and socio-cultural aspect by planning and management of tourism. The article presents historical background of the idea of sustainability and main international events concerning this topic. The author highlights negative effects of tourism that can be prevented by applying the principles of sustainable development.

KEYWORDS: sustainable tourism, responsible tourism, ecotourism.
\end{abstract}

JEL CODES: L830, Q010

\section{Introduction}

Sustainability is a popular trend in nowadays life, concerning development and operation, also in tourism sector. However, there is confusion about the different meanings of sustainability and whether it can be achieved in tourism. Therefore a problem arises: does sustainable development apply to tourism? The purpose of this paper is to reveal the necessity of sustainable development in tourism due to limited resources and significant concern about environment that are to be used by future generations. The object of this article is to present sustainable tourism: concept, definition and historical background. Moreover, the author presents its own critical view on the sustainable tourism development in Poland - current situation and the need for change. The tasks arising from the purpose are as following: to present economic aspect, environmental aspect and socio-cultural aspect influencing sustainable tourism. Monographic and descriptive method was applied in the paper. It is worth emphasizing that there is a large number of American and English literature on the topic. Sustainable tourism is a term often explained, described and used in Western tourism handbooks, sometimes even as a separate publication. However, there is not much literature in Polish publications. It may be due to low level of development of tourism sector in Poland as a science on tourism is rather young and not well developed yet. The other reason may be little interest in the issue of sustainability among touristic facility management. Most of Polish literature base on foreign bibliography and international documents introducing sustainability principles.

\section{Legislation and historical background}

Rapid socio-economic development based on the use of natural resources such as space, mineral resources and water degraded environment to such an extent that it became necessary to revise rules for the use of

Iwona Niedziółka - M.A. Alcide De Gasperi University of Euroregional Economy in Józefów (Poland). Scientific interest: tourism law, European law, customer and competition protection.

E-mail: iwona@wsge.edu.pl

Tel.: +48227891903. 
the environment. Taking into account the irreversibility and limitations of many elements of the natural environment, the increasing level of interference in the natural environment through the exploitation, destruction and pollution will lead to a situation in which the socio-economic development is impossible without resources. The main role in building awareness about environmental degradation and the depletion of its resources have played in the report "The Limits to Growth" by D. L. Meadows and "Man and His Environment" by U'Thant that were published in the late 60s. These became the foundation for international discussions.

In the early 1970s the first United Nations (UNEP) Conference on the Human Environment chaired by U'Thant than UN Secretary-General took place in Stockholm. It produced an action plan for the environment based on:

- the global environmental assessment programme - Earthwatch;

- environmental management activities;

- international measured to support the national and international actions of assessment and management (Cooper, Fletcher, Fyall, Gilbert, Wanhill, 2008).

The Stockholm Conference resulted in commissioning of the World Conservation Strategy which can be seen as implementation measure of the human environmental action plan.

The next landmark in the pathway to sustainability was the Brundtland Report "Our Common Future" in 1987 provided by World Commission on Environment and Development (WCED), called Brundtland Commission after the name of chairman Gro Harlem Brundtland former Prime Minister of Norway due to her strong background in sciences and health. One of the commission's primary goals was to: "help define shared perceptions of long-term environmental issues and the appropriate efforts needed to deal successfully with the problems of protecting and enhancing the environment, a long-term agenda for action during the coming decades, and aspiration goals of the world community" (Cooper, Fletcher, Fyall, Gilbert, Wanhill, 2008). The document adopts a definition of sustainable development as following: "Sustainable development is development that meets the needs of the present without compromising the ability of future generations to meet their own needs." The Brundtland Report has been criticized on the grounds that many of its plans did not materialize but it provided a valuable platform for the debate.

The impact of this document soon led to the UN organizing a major international conference on the topic. Within 5 years of the Bruntdland Report the Earth Summit (The Conference on Environment and Development) was held in Rio de Janeiro in 1992. The conference put down a landmark on sustainability in the form of a broad action strategy known as Agenda 21. Although tourism neither appeared as an issue in Brutdland Report, nor was included in Agenda, the industry's planning and development have been heavily influenced by their recommendations (Holloway, 2009). The result of the conference was also a document containing the fundamental principles on which the state policy on socio-economic development should be based taking into account environmental conditions, the so called Rio Declaration containing 27 principles defining the rights and duties of nations in terms of sustainable development.

The year 1992 was a crucial year for sustainability. The hospitality industry launched its International Hotel Environment Initiative (IHEI), designed to reduce the impact of staying visitors on the environment. Also, the same year the UK-based pressure group Tourism Concern set out its own guidelines and begun actively to lobby the private sector to take more account of the need for sustainable planning.

Tourism Concern guidelines:

1. Using resources sustainably;

2. Reducing overconsumption and waste;

3. Maintaining diversity;

4. Integrating tourism into planning;

5. Supporting local economies;

6. Involving local economies;

7. Consulting stakeholders and the public;

8. Training staff; 
9. Marketing tourism responsibly;

10. Undertaking research.

These principles appear to achieve more balance between socio-cultural and environmental elements (Holloway, 2009).

It is very important to mention here also the Kyoto Protocol from 1997 aimed to reduce green house effect by limiting $\mathrm{CO}_{2}$ emissions. Tourism is the center stage in these concerns because travel for leisure purposes is not a fundamental necessity and it contributes to $\mathrm{CO}_{2}$ emissions through the consumption of fossil fuels used to transport people on holiday, at the destination and in the accommodation they use. The transport causes around $75 \%$ of the $\mathrm{CO}_{2}$ emissions generated by tourism, with aviation responsible for around $40 \%$. Improving energy efficiency in transportation may be expected to generate a reduction of $32 \%$ in the emissions per passenger kilometer between 2005 and 2035. However, the quantity of emissions varies depending on the mode of transport used, with long-haul travel the greatest contributor to highly emission-intense trips (Page, 2011).

At the beginning of the XXIst century the idea of sustainable tourism has become more popular among public sector which is responsible for planning and strategy and also private, i.e. travelling and touristic enterprises. The United Nations Environmental Programme (UNEP) introduced its Initiative for Sustainable Tourism, which was aimed at tour operators. This was followed by the UN declaration to designate the year 2002 as the International Year of Ecotourism. Later-on a World Summit on Sustainable Development was held in Johannesburg (also called "Rio+10"). This initiative for the first time stressed the importance of sustainable development in tourism. Moreover a world eco-tourism summit was held in Quebec in the same year.

Other organizations connected to the industry such as World Tourism Organization (UNWTO) or the World Travel and Tourism Council (WTTC) contributed to the principles of sustainable development, which aims to minimize damage the environment, wildlife and local populations caused by tourists and the industry. Together with the Earth Council they encourage the industry to take the lead in preserving the environment in the areas they operate. The future will show if there is a true will among governments to implement the global strategies and actions that were set out more than a decade ago.

\section{Concept of sustainability}

To explore the principles and objectives of sustainable development in tourism first it is necessary to define the term "sustainable development". Despite the widespread acceptance of sustainable development, there remains a lack of consensus over the actual meaning of this term. It means different things to different people and can be applied to many context, including tourism. Nonetheless, the most general but accurate is the definition provided by the Bruntdland Report: "Sustainable development is one that meets the needs of the present generation without comprising the ability for future generations to meet their own needs". This definition identifies basic principles of sustainability, such as:

- takes a holistic approach to planning and strategy;

- protects the environment (biodiversity) and man-made heritage;

- preserves the essential ecological processes;

- facilitates and engages public participation;

- ensures that productivity can be sustained into the long-term future.

- provides for a better level of fairness and opportunity between different countries. (Cooper, Fletcher, Fyall, Gilbert, Wanhill, 2008).

The concept of sustainable development (variously described as eco-development, self-sustaining development or suspensory development). Sustainable development is based on three pillars: economic development, environmental protection and social development. Recently the term "social development" is being replaced as the "socio-cultural development". This concept assumes properly and consciously shaped 
relationship between the pillars, which are intended to ensure intra- and inter-generational economic, environmental and social balance (Meyer, Milewski, 2009: 84).

Currently concepts of sustainability are included in the vast majority of regional development strategies; the term appears even in the Polish Constitution.

Sustainable tourism is defined as all forms of activities, management and development of tourism that preserve natural, economic and social integrity and guarantee maintenance of natural and cultural resources.

Sustainable tourism development guidelines and management practices are applicable to all forms of tourism in all types of destinations, including mass tourism and the various niche tourism segments.

Thus, implementation of sustainable tourism principles requires:

- Making optimal use of environmental resources that constitute a key element in tourism development, maintaining essential ecological processes and helping to conserve natural heritage and biodiversity.

- Respecting the socio-cultural authenticity of host communities, conserve their built and living cultural heritage and traditional values, and contribute to inter-cultural understanding and tolerance.

- Ensuring viable, long-term economic operations, providing socio-economic benefits to all stakeholders that are fairly distributed, including stable employment and income-earning opportunities and social services to host communities, and contributing to poverty alleviation (UNEP, 2004).

Sustainable tourism development requires the informed participation of all relevant stakeholders, as well as strong political leadership to ensure wide participation and consensus building. Achieving sustainable tourism is a continuous process and it requires constant monitoring of impacts, introducing the necessary preventive and/or corrective measures whenever necessary. Sustainable tourism should also maintain a high level of tourist satisfaction and ensure a meaningful experience to the tourists, raising their awareness about sustainability issues and promoting sustainable tourism practices amongst them.

Sustainable tourism concerns particularly important aspects such as competitive and socially responsible tourism businesses, the opportunity to participate in tourism for all citizens, good employment opportunities in the sector and benefit from tourism activities for the local community. This requires the preservation of cultural integrity and the integration of environmental protection and cultural heritage resources in programs related to tourism. Extensive attempts to implement the principles of sustainable tourism development are made both at the regional level and at the level of tourism enterprises.

A specific kind of sustainable tourism is "eco-tourism" defined by The International Ecotourism Society as the responsible travel to natural areas that preserve the environment and sustain the local people welfare. It includes at the same time elements of rural and cultural tourism. Besides subscribing to the principles of sustainable tourism, ecotourism has specific principles: it contributes actively to the conservation of natural and cultural heritage, it includes local communities in planning, development and operation activities, and it contributes to their welfare, it involves complete and interesting explanations for visitors, regarding the natural and cultural resources, it is intended mainly to individual visitors and also to small organized groups. This kind of tourism often includes activities in nature such as: hiking, mountain climbing, observing the living beings in their natural habitat, etc. Moreover, it can also incorporate cultural activities, too. Ecotourism plays an important role in education, it is a chance to learn respect for nature, for the local culture, and for some it is a chance to self-reflection being inspired by the beauty of the surroundings. Another characteristic aspect of ecotourism is to obtain benefits for the local community. This means hiring local staff, sourcing local products, local involvement in decision making and organization of tourist activities (Sambotin, Sambotin, Patrascoiu, Coroian, Merce, 2011).

\section{Principles of sustainable development in tourism enterprises}

The principles of sustainable development in tourism enterprises is applied relatively rare. It is due to the fact that tourism businesses in the economic calculation do not include (or include to a limited extent) the social costs and costs related to environmental protection. In practice, the most common solutions are 
those that are inexpensive (printing booklets, marking the site, etc.) helping to reduce costs (energy saving in hotels, recycling), allow for better positioning of the brand companies to distinguish themselves from the competition, induce a positive reaction of customers (see: Sharpley, Telfer, 2008).

The most important barriers to the application of the principles of sustainable development by companies should include a lack of awareness of the problem, the need to reduce costs and lack of conviction that the use of such practices can be reflected in an increased number of clients. Among tourism enterprises organizers of tourism and ship-owners rarely apply the principles of sustainable development (mainly due to the high level of variable costs and the high elasticity of demand), while the transport undertakings and hotel management often include sustainable principles when shaping their product (due to higher share of less price-sensitive business customers). The introduction of these principles by companies is also influenced by their surroundings (in Northern Europe organizations apply the principles of sustainable development more often than in the Mediterranean) and size (larger companies often use this type of practice) (Meyer, Milewski, 2009).

Local Agenda 21 is a comprehensive plan of action to be taken locally by organizations and local authorities in every area in which human impacts on the environment. It is a kind of guide on how to plan regional development according to the principles of sustainability. Local Agenda 21 processes emphasize a cooperative approach to identifying the community's goal for tourism and creating an action plan to achieve these goals (UNEP, 2003; see also Kazimierczak, 2005).

\section{Aims of sustainable tourism}

The main aim of creating strategy of sustainable tourism for a given region is defined as an increase of the number of tourists with the principles of sustainable development. This aim can be achieved by a number of specific objectives, such as:

- coordination of all parties interested in developing of tourism in the region;

- inventory of area tourism product;

- consideration of the interests of local communities and the environment in shaping the tourism product and marketing activities;

- assessment of marketing and product perception by potential buyers;

- developing a vision, mission and framework marketing plan activities for the duration of the strategy;

- developing a common brand of region;

- developing tools to evaluate progress in implementing the strategy (Meyer, Milewski, 2009).

As sustainability is considered in 3 contexts: economical, environmental and socio-cultural it is necessary to divide aims of sustainable tourism also in those 3 aspects.

\subsection{Economical aspects of sustainable tourism}

\section{a) Economic profitability}

Ensuring the viability and competitiveness of regions and businesses to achieve long-term viability;

b) Local prosperity

Maximizing the economic benefits of tourism to the local community, including the expenditure of tourists in the area;

c) Quality of employment

Increasing the quantity and quality of jobs related to tourism in the local community, including wages, work environment and employment opportunities without discrimination;

d) Social equity

Ensuring fair and equal distribution of social and economic benefits coming from tourism (Panasiuk, 2011: 110). 


\subsection{Environmental aspects of sustainable tourism}

a) Physical integrity

Maintaining and building quality of the landscape, in both urban and rural areas and preventing form ecological and visual pollution;

b) Biological diversity

Promoting and protecting environment, natural habitats and wildlife, as well as minimizing the impact of tourism on the environment;

c) Effective waste management

Minimizing of the use of rare and non-renewable resources in the development of tourism;

d) Clean environment

Minimizing of water, air, soil pollution and reduction of generating waste by tourists and tourist operators (Panasiuk, 2011).

\subsection{Socio-cultural aspects of sustainable tourism}

\section{a) Welfare of the community}

Building welfare of the community including social infrastructure, access to resources, environmental quality and avoidance of social corruption and the exploitation of the resources;

b) Cultural wealth

Maintaining and developing cultural heritage, local culture, customs, and the exceptional nature of the host community;

c) Meeting expectations of visitors

Providing safe and enjoyable tourist experience, which will meet the needs of tourists and will be available to all?

\section{d) Local control}

Authority for planning and decision-making in the management of tourism by local communities (Panasiuk, 2011).

\section{Sustainable tourism in Poland}

Although the term 'ecotourism' 'sustainable tourism' is very fashionable, as for now it is mostly a theoretical approach. There are some single examples of 'eco-hotels' like the world-wide famous InterContinental Hotels Group (IHG) on Bora Bora or a Polish hotel in Bysłowiec, but generally tourism and especially hospitality sector is slowly changing into a more eco-friendly branch.

Despite that Polish hotel managers are often well aware of the concept of ecology and sustainability, this fact does not play an important role in marketing campaigns yet ${ }^{2}$. It can be caused by few factors. Customers of polish accommodation services may not be conscious of the idea of eco-hotels or may not be interested of such hotel service providers. The second possible reason is that eco-hotels might be seen as more expensive due to their 'innovative' and 'modern' systems.

The idea is emerging on Polish hostelling market slowly. Polish Hotel Association (Polskie Zrzeszenie Hoteli) is preparing the first eco-label "EKOHOTEL". Moreover, more hotel managers apply to get ISO 14001 standard prepared by Eco Management and Audit Scheme and European standard of management (Pasko, Staszewska-Ludwiczak, 2008).

Within the ever changing standards on the market it is supposed that more entrepreneurs will try to acquire some certificates confirming their aspirations to be more social responsible.

2 According to the research made by Paulina Bohdanowicz in $200282.7 \%$ of respondents think that environmental protection is a key aspect of welfare and further development of tourism. However, only $10 \%$ of hotel managers use this fact in advertisements. See: www.serwis-hotelarski.gastroma.pl/art/article_3276.php. 
Nevertheless, probably most of hotel managers are interested in being recognized more eco-friendly only for financial reasons. Reduction of running costs is the most important incentive for encouraging environmental actions. Most of introduced innovative technologies are based on energy-saving or reducing waste production systems, such as: making use of renewable energy resources (wind, geothermal, tides, sun-light energy etc. in Poland reached level of $8 \%$ in 2010 according to Polish Economic Chamber of Renewable Energy $)^{3}$ or effective systems of building insulation. The reduction of the usage of water is reached by installation of 'economic' system of water flush or water aerators in taps. Hotels use labels enhancing consumers to save water, not to change towels every day etc.

All those technologies and incentives used in hotels are welcome. However, they are introduced mostly for economic reason. Other postulates such as waste recycling are not that readily introduced by managers.

In this situation it is difficult to declare whether legal requirements will strengthen or hamper development towards sustainability.

Accommodation is only one branch in whole tourism sector. The most energy is used in transportation. Here not lot can be done by a single entrepreneur or by consumer. Tourists have no influence on the usage of fuel for planes, ships, trains or buses. Traveling and transportation is bound with technology development.

As it comes to economic and socio-cultural aspect of tourism in Poland it is comparative to the rest of world, as written in section 6 - impact of tourism.

\section{The impacts of tourism}

The need to apply the principles of sustainable development in tourism sector is very important from the point of functioning of this sector, as it is directly and indirectly dependent on natural resources and their quality. Meanwhile tourism activities contribute to both positive and negative effects in all three aspects of sustainability.

\subsection{Economic impact}

The development of tourism in a country or region is recognized as a huge economic opportunity to reduce poverty by generated income and employment. However, if tourism is not developed and managed responsibly, taking into account local needs and concerns, the actual economic benefits may be substantially less than expected.

The main three economic benefits of tourism are: reduction of unemployment, development of infrastructure and financial and non-financial income to the region.

The increased spending power of employees and their families that results from more tourism jobs. Moreover, economic benefits can sometimes be induced in a place a long way from the tourism destination or holiday: for instance, cruise ship workers often send their wages back to their home countries.

Tourism as every other industry needs a well-developed infrastructure network. This means not only roads and rail tracks, but also social and cultural infrastructure, such as restaurants, pubs, hospitals, theaters, cinemas, entertainment centers etc.

Direct benefits are all money that comes to the region in a form of expenditure by tourists at the destination for food, souvenirs, excursions, tips, etc. They also include money paid by tour operators to local suppliers, including hotels and local transport companies. Indirect benefits include income generated by goods and services provided to the tourists. For example, food purchased by the hotels can provide jobs and revenues for local farmers or factories. Maximizing the use of local products can increase these indirect impacts, meaning that a destination needs fewer tourists to generate the same economic benefit.

The key manner in which local populations fail to benefit from tourism is through revenue 'leakages' when the goods and services used in tourism are produced and purchased outside the country or region. In addition, government expenditure on tourism infrastructure, such as sanitation, roads, airports or health

\footnotetext{
3 http://www.pigeo.org.pl
} 
facilities, may mean that less funds are available for basic services for the local population. Other potential costs include the expense of addressing air and water pollution generated by tourist activities, losses to the economy caused by illness related to pollution, and an increased cost of living for local people, as tourist.

Moreover, an inflation of prices of goods and services in high-season can be noticed. Labor barrier occurs in the absence of an adequate number of workers willing and have the relevant qualifications to work in tourism.

\subsection{Environmental impact}

Tourism can have wide-ranging and sometimes irreversible negative impacts on the environment. In some of the most extreme cases, long-term environmental degradation has destroyed the very features that once attracted tourists to a place, leading tour operators and their clients to abandon the older destination in favor of new, undamaged ones. Not properly planned tourism can lead to landscape degradation and biodiversity loss through the conversion of natural habitats and damage to coastal areas, forests, coral reefs and other ecosystems (Sitek, 2007). Most vulnerable to degradation are considered particularly vulnerable areas with high natural values, including coastal areas, alpine areas, freshwater ecosystems and Antarctic and Arctic coasts (Panasiuk, 2011).

Tourism contributes to the disorder of water balance, generates the waste produced by tourism enterprises and tourists themselves. Transportation to tourism destinations has global impact through the carbon dioxide emissions of airplanes and other forms of transportation that contribute to human-induced climate change.

Although tourism can lead to environmental costs, it can also be a source of benefits for the environment. The revenues generated thanks to tourism sector can contribute significantly to preservation of protected areas, such as: coral reefs or forests. Moreover, ecotourism can help promoting eco-friendly way leisure. Corporate social responsibility introduces standards that will conserve water and energy and reduce waste generation etc. (UNEP/WTO, 2005).

At this point it should be noticed that tourism will always have negative influence on environment like every other industry. Nevertheless it should be a priority to lower the negative effects as much as possible, even if they cannot be all eliminated.

\subsection{Socio-cultural impact}

Negative consequences of tourism development are associated with changes in the local social environment. Foreign guests often disturb in local way of life and social structures and practices. Local culture is commercialized, authenticity of the regional culture diasporas. There is an increasing number of social conflicts and pathology of the local population.

Tour operators can help encourage positive cultural changes and prevent negative impacts by supporting local enterprises and encouraging appropriate behavior by tourists. Disseminating information on appropriate behavior to clients and reducing the opportunities for them to display inappropriate behavior may help to reduce the chances of conflict and cultural disruption (UNEP, 2005).

The model below presents an example of the relationship between tourism and local policy taking into account economic, socio-cultural and environmental aspects. Three main aspects make up the tourism industry and its impact on sustainability i.e. transportation, accommodation services and purpose of travel. Those three separately also have impact on destination place but seen altogether present more general view on the model. The model stresses the importance of responsible managing of tourist traffic.

\section{Recommendations}

Sustainable development principles are applied in tourism mostly when they are seen as profitable. Entrepreneurs in hospitality industry (i.e. providing accommodation service) introduce environmental friendly solutions mostly because of economical reason. It can also be seen as an advantage from marketing point of view. Eco-labels may attract customers - tourists to specific destinations. 


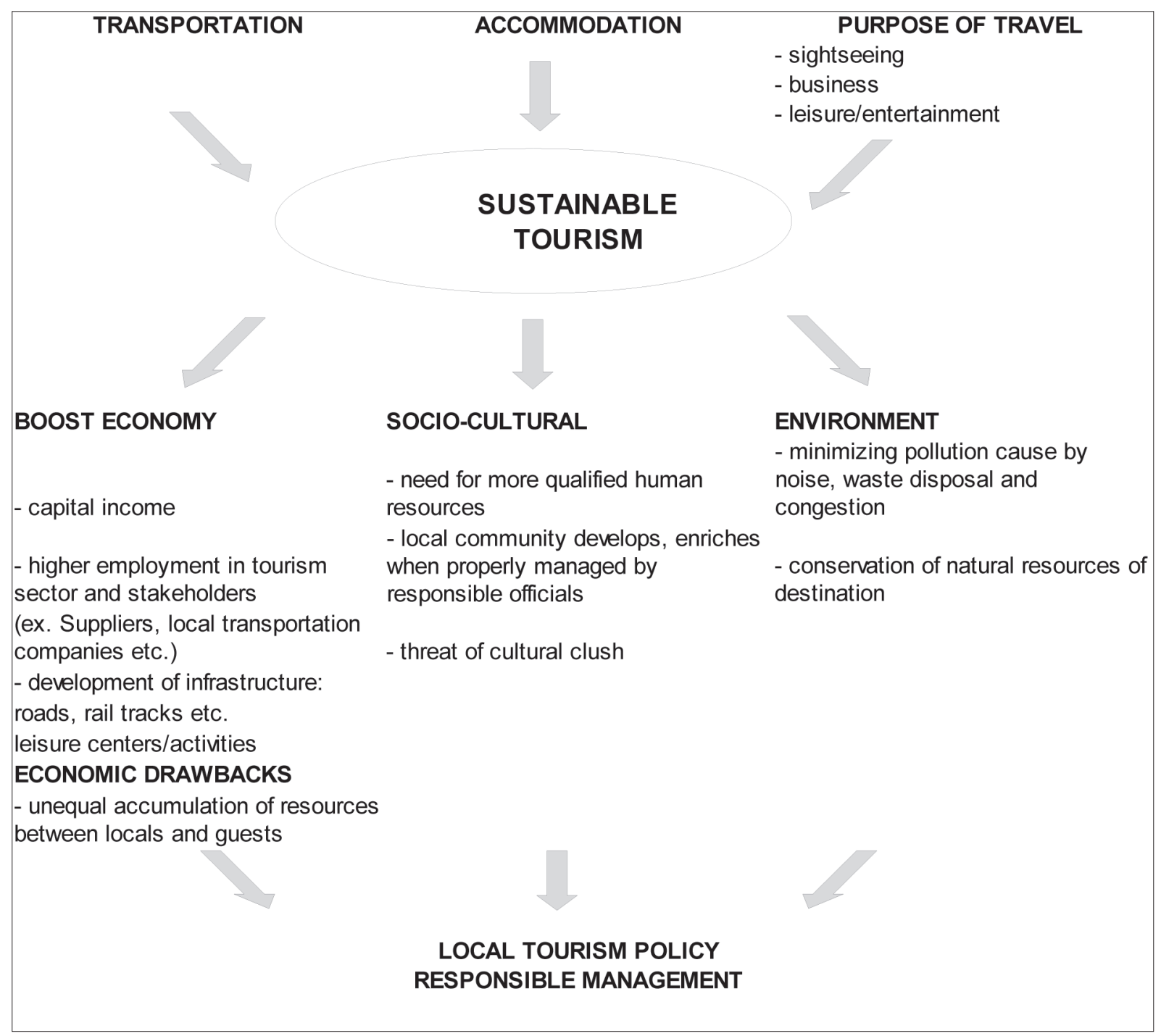

Figure 1. Example of functioning of tourism in destination place with its connection to local policy and management of tourist traffic

Tourism may harm local communities by interference of outsiders to the society in destination place. From another point of view, however, tourism can help preserving cultural heritage. Historical sites are being renovated and protected to attract visitors, although they will last in origin destination for future generations.

It is recommended to put more emphasis on education of tourists, when it comes to their contact with local communities. More respect and understanding should be given to the hosts. Furthermore, accommodation entrepreneurs should consider more, not only current needs of their clients, but also future needs of local community. They ought to understand that without the cooperation with host society, consideration of the environment, they cannot survive as an attractive tourist destination.

\section{Conclusions}

Application of sustainability principles is the best way to preserve tourism destinations from degradation in social, cultural and environmental way. Tourism, properly planned can also increase income and be source of wealth of local community. Tour operators are able to attract capital from banks and investors, therefore tourism may be seen as easy way to access to capital. Sustainable actions can help lower operating costs by reducing generation of waste and usage of water and energy. However, more qualified employees are needed, therefore 
human capital will also grow. A reputation for being sustainable adds value to touristic enterprises' brands and strengthens their market position, making them less vulnerable to short-term market and economic changes.

In this way introducing principles of sustainable development, however is an expensive process, it can be profitable in long term perspective.

\section{References}

Cooper, C., Fletcher, J., Fyall, A., Gilbert, D., Wanhill, S. (2008). Tourism Principles and Practice. England: Pearsons Education Limited.

Holloway, J. C. (2009). The business of tourism. England: Pearsons Education Limited.

Integrating Sustainability into business. A Management Guide for Responsible Tour Operations. (2005). France, UNEP.

Kazimierczak, M. (2005). The ethics of sustainable development in tourism of postindustrial age. Poznań, Wydawnictwo Wyższa Szkoła Hotelarstwa i Gastronomii w Poznaniu.

Making Tourism More Sustainable. A Guide for Policy Makers. (2005). France/Spain, UNEP/WTO.

Meyer, B., Milewski, D. (2009) Strategie rozwoju turystyki w regionie. Wydawnictwo Naukowe PWN.

Page, S. J. (2011). Tourism Management. An Introduction. Butterworth-Heinemann.

Panasiuk, A. (red.) (2011). Ekonomika turystyki i rekreacji. Wydawnictwo Naukowe PWN.

Pasko, K., Staszewska-Ludwiczak, A. (2008). "Green hotels" - hotele przyjazne środowisku - innowacyjna działalność w hotelarstwie. In: D. Chudy-Hyski, M. Żemła (red.). Turystyka - Innowacje - Konsument. Górnośląska Wyższa Szkoła Handlowa im. Wojciecha Korfantego.

Sâmbotin, D., Sâmbotin, A., Patrascoiu, M., Coroian, A., Merce, I. I. (2011). Ecotourism - a model of sustainable development of tourism means. Journal Lucrari Stiintifice, Universitatea de Stiinte Agricole Si Medicina Veterinara a Banatului, Timisoara, Seria I, Management Agricol, Vol. 13, No. 4, p. 221-226.

Sitek, M. (2007). Polityka ochrony środowiska w sektorze ushug turystycznych w świetle prawa Unii Europejskiej. Olsztyn: Wydawnictwo Uniwersytetu Warmińsko-Mazurskiego.

Sharpley, R., Telfer, D. (2008). Tourism and Development. USA: Taylor\&Francis Group.

Tourism and Local Agenda 21. The Role of Local Authorities in Sustainable Tourism. (2003). France/Germany, UNEP/ ICLEI.

United Nations Environment Programme. (2004). Sustainable Tourism: Definition. Website: http://www.unep.fr/scp/ tourism/sustain/ (13.05.2012).

Website: http://www.pigeo.org.pl

Website: http://www.serwis-hotelarski.gastroma.pl/art/article_3276.php.

\section{DARNAUS TURIZMOVYSTYMAS}

IwONA NiEDZIÓŁKA

Alcide De Gasperi Euroregionines Ekonomikos Universitetas, Józefów (Lenkija)

\section{Santrauka}

Šiame straipsnyje pateikiamos pagrindinès darnaus turizmo - naujos turizmo formos, kurią skatina valdžia, aplinkosauginès ir socialinès institucijos bei tarptautinès organizacijos. Ji lemia ekonominių, aplinkosauginių ir sociokultūrinių aspektų i̇vertinimą turizmo valdymo srityje. Straipsnyje pateikiama istorinè darnumo idejjos kilmè ir pagrindiniai tarptautiniai ịvykiai, susiję su šia tema. Autorius atskleidžia neigiamą turizmo poveiki, kurio galima išvengti taikant darnaus vystymosi principus.

PAGRINDINIAI ŽODŽIAI: darnus turizmas, atsakingas turizmas, ekoturizmas.

JEL KODAI: L830, Q010 